\title{
(ISES) Intelligent Smart Energy Stiller
}

\author{
Abdelrahman Salem \\ STEM Egypt school 2014-2017 \\ Faculty of Dentistry, Ain Shams University 2017 - \\ DOI: 10.29322/IJSRP.10.10.2020.p10621 \\ http://dx.doi.org/10.29322/IJSRP.10.10.2020.p10621
}

\begin{abstract}
Lack of water resources and water pollution are some of the major hazards to the security of our water. Do you know the amount of water that consumed and produced in Egypt?

This year Egypt's water needs stand at 76 billion cubic meters and will keep increasing dramatically in a direct relation with increase of the population. The River Nile supplies Egypt with about 55.5 billion cubic meters each year which represents about $69.8 \%$ of Egypt's water needs. Moreover, citizens still depend on the fresh water as the main source to obtain drinkable water. In addition, there are about 38 million Egyptian citizens suffering from the water pollution issue, in addition, about 5.4 tons of pollutants are being thrown into water every year? Therefore, the problem mainly was the lack of clean water resources.

In this project, we are attempting to depend on seawater as a major source for the drinkable water. We will evaporate the seawater by depending on the sunrays to evaporate salty water and get distilled water ${ }^{[3]}$.
\end{abstract}

Index Terms- Reflector - Heater - Solar energy - LDR - Arduino

\section{INTRODUCTION}

$\mathrm{I}$ is well known that Egypt faces several severe problems and grand challenges and the lack of the clean water resources is one of them, as shown in figure 1. The problem of the leakage of the water clean resources is a problem that the whole world suffers from now ${ }^{[3]}$.

Most of the trials are about how to rely on another sources and the more common source is the water from seas and oceans.

This water are somehow clean except that there are some salts and small amounts of impurities that must be cleaned. There are many ways to treat these water like the RO systems and Carbon nanotubes and using natural light and heat energy to evaporate the water. We found that depending on natural light and energy is cheap, efficient, and keep the environment clean because we didn't burnany fossil fuel to get energy. We have used benefit of sun heater idea, and we used glass tube, dark black tube, parabola reflector, LDR, and Arduino.

We hope that this project will meet the design requirements tested by our prototype that to decrease the energy used so there would be a decreasing in the cost and being green to the environment.
Figure 1

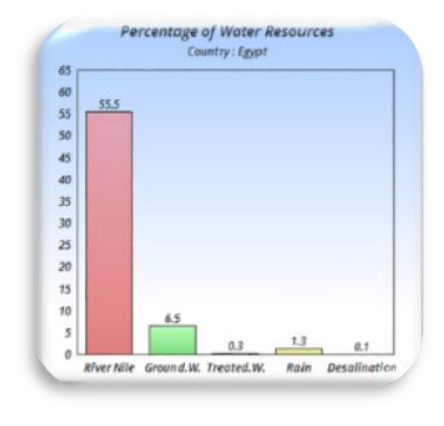

\section{MATERIALS \& METHODS}

We used a variety of materials to build the prototype and perform our test plan as shown in the following. Materials and Methods of performing the test plan. We decided to turn our idea into a real model by performing a simple prototype that will express the whole idea. In order to make this prototype. Therefore, we used the following materials: glass tube, PVC tube, black metal tube, reflector, condenser, thermal insulator, silicon, glue, arduino board, LDR, bread board, servo motor, resistors and jumpers.

\section{RESULTS}

After we had determined our design requirements which are high efficiency, clean environment and cast. We tried to test our prototype. We started our experiments to test our design requirements:-

\section{Efficiency:}

Firstly, we did our experiment in different conditions such as: sunny day and cloudy day distilled water we found that the average of the distilled water is near to the ideal results that is from 8 to 10 liters per day, so our prototype achieve efficiency higher than the plants which evaporate the seawater by

using electricity or fuel. Also if we use large scale we will find the results in the following table:-

\section{Cost:}

We've calculated the price of every liter of water that we produce and calculated the price of every liter that produced by government water treatment plants, then we've compared the two prices of them as shown in tables 1 and 2 . 
Our liter casted the price of the energy that used to treatment only ( 2.5 watt per hour, 10 watt per 4 hours, 30 watt per day, .9 kilo watt monthly) and produced approximately 37.5 liter per 4 hours (0.004 L.E for liter) is lower than the government liter cost (0.05 L.E for liter), we've succeeded to achieve this design requirement. In addition, the following table represent the results of this test plan. Note:- Whole of these data collected by considering that our scale is 2 meter square.

Table I:

\begin{tabular}{|l|l|l|}
\hline Day condition & Project's scale (meter square) & Production (Liter) \\
\hline Sunny day & 2 & $18.75 \mathrm{~L}$ \\
\hline Sunny day & 5 & $46.8 \mathrm{~L}$ \\
\hline Sunny day & 10 & $93.75 \mathrm{~L}$ \\
\hline Cloudy day & 2 & $13.125 \mathrm{~L}$ \\
\hline Cloudy day & 5 & $32.8 \mathrm{~L}$ \\
\hline Cloudy day & 10 & $65.6 \mathrm{~L}$ \\
\hline & & \\
\hline
\end{tabular}

Table II:

\begin{tabular}{|l|l|l|l|}
\hline $\begin{array}{l}\text { Amount of energy that we } \\
\text { used }\end{array}$ & $\begin{array}{l}\text { Amount of water that we } \\
\text { produced }\end{array}$ & Price of our water & $\begin{array}{l}\text { Price of government } \\
\text { water }\end{array}$ \\
\hline 2.5 watt & $18.75 \mathrm{~L}$ & .004 L.E & .95 L.E \\
\hline 7.5 watt & $56.25 \mathrm{~L}$ & .012 L.E & 2.85 L.E \\
\hline 25 watt & $187.5 \mathrm{~L}$ & .04 L.E & 9.5 L.E \\
\hline 50 watt & $562.5 \mathrm{~L}$ & .08 L.E & 19 L.E \\
\hline
\end{tabular}

\section{Eco-friendly:}

Finally, after we had done our experiments we did not observe any exhausted like carbon dioxide or fumes Emit from the prototype. In addition, it did not affect the environment badly and keep the human health, as shown in the following real figures 2 and 3. 


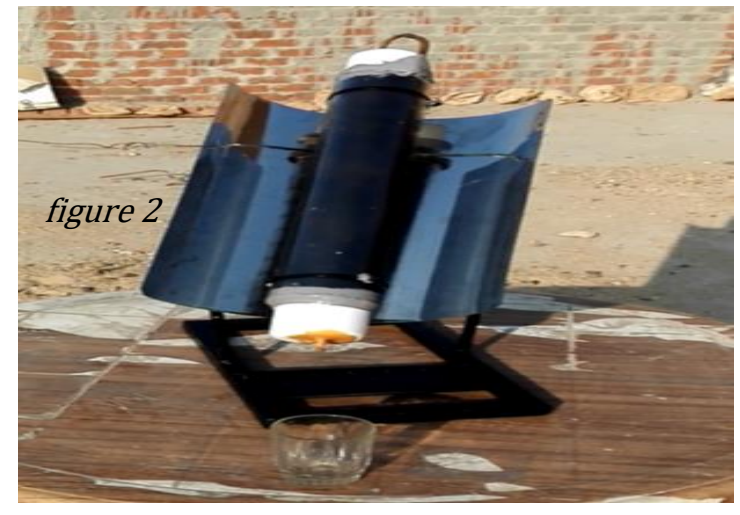

figure 3

\section{Discussion}

The right to sustainable water is the right of everyone to enjoy safe and clean water. However, Egypt suffers from many water problems that may prevent its development such as: Water Pollution, Lack of Water Supplies, and Spread of Diseases. As shown in the following figures. There are about 9 million cubic meters of fresh water that are wasted annually in Egypt by different human activities like washing, showering or in toilets.

The right to sustainable water is the right of everyone to enjoy safe and clean water. However, Egypt suffers from many water problems that may prevent its development such as: Water Pollution, Lack of Water Supplies, and Spread of Diseases. As shown in the following figures. There are about 9 million cubic meters of fresh water that are wasted annually in Egypt by different human activities like washing, showering or in toilets.

The reflector is put behind the prototype to reflect the rays of the sun to make the prototype face the sun from every directions. The dark tube absorb the rays of sun and help to increase the temperature, and the small gab between the glass tube and the drack tube help to increase the speed of evaporation because of decreasing the amount of seawater, so the water will evaporate ${ }^{[1]}$. After water evaporating, the water vapor rises and get into the condenser, and it condenses in the condenser then, the water turns into distilled water without any salts.

There's an electronics part to control the moving of the prototype by using Arduino, LDR, motor and arm to make the prototype move with the sun (as shown in the previous figure).

Solar radiations spans a wide spectrum beyond the visible range of light. It is estimated that $44 \%$ of the light emitted by the Sun is visible with $7 \%$ in the ultraviolet range and $49 \%$ in the infrared range. When visible light impacts with the surface of the Earth or its atmosphere, it loses much of its energy in the process and most of this is later emitted back into space as longer wavelength infrared radiation.

Capturing this energy using a Nano antenna array could serve two important purposes. The energy could be used to power numerous electronic devices, and it could also be drawn away from equipment like computer

There are factors effect on the result of the project like (Temperature, Amount of water, Gab between the glassy tube and the dark tube, and ratio of salt in water).

The prototype also showed the ability to work properly and end the processes without losses in any stage. Its electrodes decays

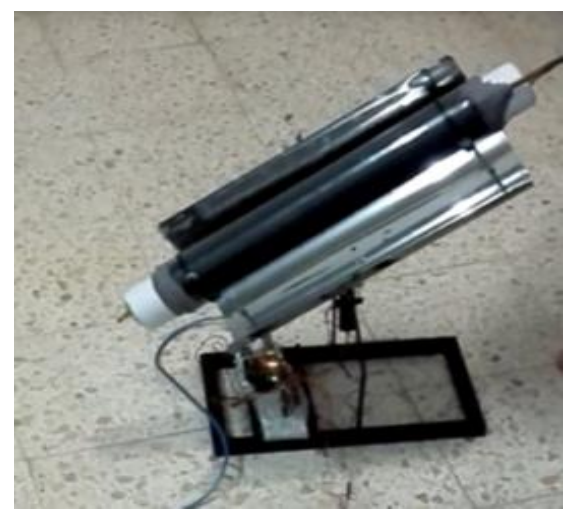

after a while as result of the chemical reaction. That could be concluded from the hypotheses that we used to construct the prototype. The results are verified and administrated by "Dr. Mohammed Abdel Aziz" and written in a way that can be repeated. Moreover, the percentage of error and tools used in the test are previously mentioned.

\section{CONCLUSION:}

The solution was chosen but our research will never end. We really aim to design a practical solution for Egypt's water challenge. So we put in our plans some topics of research to improve our solution.

We are going to do research about use the micro controllers to make the prototype depends on it only in its move, and make the prototype work at night by using solar cells and store its energy in a battery then use this energy at night by using it to work electric heater to evaporate water at night.

In addition, we recommend putting in mind the possibility of finding out more efficient materials that offer very high permeability of water ${ }^{[2]}$.

In addition, we are going to increase the efficiency of our project by decreasing the gap between the glassy tube and the dark tube by using the equation:

$\mathrm{Q}=\mathrm{m}^{\ominus} \cdot \mathrm{Cp} \cdot \Delta \mathrm{T}$

$\mathrm{Q}$ is the het net, $\mathrm{m}^{\ominus}$ is the flow rate, $\mathrm{Cp}$ is constant, and $\Delta \mathrm{T}$ is Tout $-\operatorname{Tin}^{[4]}$..

Solar energy is a near perfect source of energy, one where no pollution is related to it. It causes no poisonous gasses or destruction of rain forests, thus we can depend on it in order to purify the sea water to become drinkable water. Hence the countries will be able to use our idea in different places such as:-

1) Tourist village:- for supporting their resident with drinkable water and do not rely on the fresh water which come from long distance.

2) The Coastal area that have not any sources of the drinkable also can use our idea in order to get renewable source of the drinkable water ${ }^{[5]}$. 


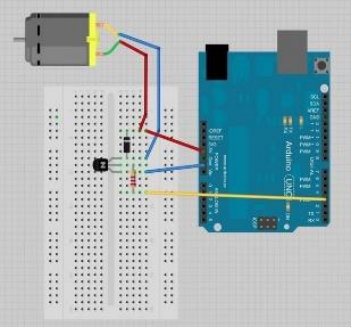

Figure 4

\section{REFERENCES}

[1] Solar Still Basics (solar still basics) http://www.solaqua.com/solstilbas.html

[2] Simple multiple wick solar still: Analysis and performance (Simple multiple wick solar still: Analysis and performance) http://www.sciencedirect.com/science/article/pii/0038092X8190075X
[3] Collect Water in a Solar Still (Desert Survival: How to Build a Solar Still) http://www.desertusa.com/desert-people/water-solar-still.html

[4] Performance analysis of double slope wick-type solar still with varying thermal insulation beneath the wick surface By: Rajanarthini, R., K. Shanmugasundaram, and B. Janarthanan. Desalination And Water Treatment

[5] Experimental investigation on the performance of solar still augmented with pin-finned wick By: Alaian, W.m., E.a. Elnegiry, and Ahmed M. Hamed. Desalination

\section{AUTHORS}

First Author - Abdelrahman Salem, STEM Egypt school 20142017, Faculty of Dentistry, Ain Shams University 2017 currently, 14070@stemegypt.edu.eg, abdelrahmansalem99@dent.asu.edu.eg, +201001568008 